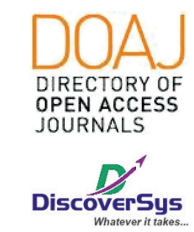

Published by DiscoverSys

\title{
Association between educational level and hypertension with decrease of cognitive function among elderly at Puskesmas Mengwi I Bali-Indonesia 2016
}

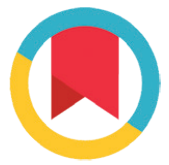

CrossMark

\author{
Vijay Ramachandran, ${ }^{1 *}$ Putu Aryani ${ }^{2}$
}

\section{ABSTRACT}

Background: One of most emerging disease in elderly is the decreasing of cognitive function. Some factors that could affect cognitive function are sociodemographic factors such as genetics, age, gender, educational level, occupation also some diseases like a cerebrovascular disease, metabolic disease, brain tumor, and head trauma.

Methods: The purpose of this research was to understand the association between educational level and hypertension with a decrease of cognitive function in elderly. This research was analytic cross-sectional study. The number of samples that obtained was 41 elderly who met the inclusion criteria. The sample data obtained by filling an MMSE questionnaire to aces cognitive function.
Results: In general, 16 from 41 sample (39\%) has a decrease in cognitive function. Bivariate analytic with chi-square method showed that there's a significant relationship between educational level and a decrease of cognitive function ( $p=0.001$ ) while also showed that there's no significant relationship between hypertension and decrease of cognitive function.

Conclusion: It can be concluded that there was a significant relationship between educational level and a decrease of cognitive function in elderly but no significant relationship between hypertension and decrease of cognitive function in elderly. The results of this study were expected to be used as a basis for further research in the future.
1Program Studi Pendidikan Dokter ${ }^{2}$ Bagian IImu Kedokteran Komunitas dan IImu Kedokteran Pencegahan,

Fakultas Kedokteran Universitas Udayana

*Correspondence to: Vijay Ramachandran, Program Studi Pendidikan Dokter, Fakultas Kedokteran Universitas Udayana vijayrams93@gmail.com

Received: 2018-01-18 Accepted: 2018-01-23 Published: 2018-01-27

Keywords: Elderly, Cognitive Function, MMSE, Educational Level, Hypertension

Cite This Article: Ramachandran,V., Aryani, P. 2018. Association between educational level and hypertension with decrease of cognitive function among elderly at Puskesmas Mengwi I Bali-Indonesia 2016. Intisari Sains Medis 9(1): 43-48. D0I: 10.1556/ism.v9i1.154

\section{ABSTRAK}

Latar Belakang: Salah satu masalah kesehatan yang sering kali muncul pada penduduk lansia adalah penurunan fungsi kognitif. Faktor-faktor yang dapat mempengaruhi fungsi kognitif diantaranya faktor sosiodemografi seperti genetik, usia, jenis kelamin, pendidikan dan pekerjaan, serta penyakit-penyakit tertentu seperti penyakit serebrovaskuler, penyakit metabolik, tumor otak, trauma kepala dan sebagainya.

Metode: Tujuan dari penelitian ini adalah untuk mengetahui hubungan antara tingkat pendidikan dan hipertensi dengan penurunan fungsi kognitif pada lansia. Penelitian analitik cross sectional ini menggunakan sampel sebanyak 41 orang sebagai responden penelitian. Pada penelitian ini subjek diminta untuk mengisi kuesioner dan dilakukan pemeriksaan status kognitif menggunakan
MMSE. Analisis data menggunakan uji chi-square dan hasil penelitian disajikan dalam bentuk tabel.

Hasil: Secara umum, didapatkan sebanyak 16 dari 41 responden $(39,0 \%)$ mengalami penurunan fungsi kognitif. Hasil analisis bivariat dengan uji chi-square terhadap tingkat pendidikan dengan penurunan fungsi kognitif menunjukkan nilai $p=0,001$. Sementara itu, didapatkan nilai $p=0,509$ pada hasil analisis dengan uji chi-square terhadap riwayat hpertensi dengan penurunan fungsi kognitif.

Simpulan: adanya hubungan yang bermakna antara tingkat pendidikan dengan penurunan fungsi kognitif, tetapi tidak ditemukannya hubungan yang bermakna antara hipertensi dengan penurunan fungsi kognitif pada lansia.

Kata kunci: Lansia, Fungsi Kognitif, MMSE, Tingkat Pendidikan, Hipertensi

Cite Pasal Ini: Ramachandran,V., Aryani, P. 2018. Association between educational level and hypertension with decrease of cognitive function among elderly at Puskesmas Mengwi I Bali-Indonesia 2016. Intisari Sains Medis 9(1): 43-48. DOI: 10.1556/ism.v9i1.154

\section{INTRODUCTION}

Indonesia is experiencing a change of demographic structure over the past few decades. This is marked by a decline in the proportion of young people aged 0-14 years, which at the same time increases the proportion of the elderly population of 60 years or older. ${ }^{1}$ Based on the Population Census in 2010, Indonesia has an elderly population of 18.04 million, representing $7.59 \%$ of the 
total population of Indonesia. Indonesia is also estimated as the fastest growing elderly country in the period 1990 to $2025 .^{2}$

Increasing the number of elderly population indirectly will bring challenges in various fields. Challenges that often arise in the field of health is relate to how to maintain the quality of life and health status of the elderly. The elderly is identical with the aging process, where aging itself has the meaning of the process of diminishing most of the functions of the physiological system and increasing susceptibility to various diseases, physiological changes that affect not only physical appearance but also everyday life function and response. ${ }^{3}$ Based on it, the elderly must achieve 'optimal aging' in life in order to maintain the quality of life and health status. In order to achieve 'optimal aging', they must be able to continue their life function as well as they can, such as being able to physically, socially and cognitively function. ${ }^{4}$

One of the health problems that often arise in the elderly population is the decline in cognitive function. Cognitive function itself is obtained through the interaction between the formal environment of education and non-formal environment that is obtained from everyday life. Cognitive function can affect the independence level of a person, disruption to cognitive function, will often impact on social life, psychic and physical activity of the elderly. ${ }^{5}$ Some risk factors that affect the occurrence of cognitive dysfunction include 60 years of age or older, genetic/hereditary, history of head trauma, lack of education, environmental factors (aluminum poisoning), certain diseases (hypertension, diabetes mellitus, stroke, down syndrome, cardiovascular disease etc.), as well as impaired immunity. ${ }^{6}$

According to Chertkow (2013), disruption to cognitive functioning involves at least two of the following five domains: (a) Disruption of the ability to acquire and recall new information. Emerging symptoms include repeated questions or conversations, errors in admitting ownership of goods, forgetting a celebration or a promise, and getting lost in places that were previously passed. (b) Disorders in understanding and doing complex tasks, making mistakes. Symptoms that can arise include difficulties in understanding a risk, difficulty in managing finances, poor decision-making ability, and difficulty in planning complex and sustainable activities. (c) Impairments in visual-spatial ability. Manifests in symptoms of inability to recognize common faces or objects or difficulty in using clothes. (d) Disorders in language functions, such as speaking, reading, writing. Symptoms that follow, among others, difficulty in thinking common words while talking, mistakes in speaking, spelling and writing. (e) Changes in behavior that can manifest as lack of motivation and initiative, apathy, desire to withdraw from social life, decreased interest in previously favored activities, lost empathy, and compulsive obsessions. ${ }^{7}$

The simple thing that can be done to reduce the risk of cognitive impairment is a lot of learning activities that function to maintain the sharpness of memory and always optimize brain function. ${ }^{3}$ Based on the theory of activities put forward Havighurst in 1952 mentioned that it is very important for the elderly to remain socially active as a tool for 'optimal aging. In addition, a study demonstrates the importance of ongoing mental and physical activity to prevent loss and maintenance of health throughout human life, where one of the mental activities is to undergo a formal education process. ${ }^{8}$ According to Larasati (2013), education is able to compensate for all neurodegenerative types and also affect brain volume. It is said that well-educated people have more brain volume and are capable of coping with cognitive and neurodegenerative improvement than low-educated people. ${ }^{9}$ A study conducted in Manado (2012), found that the elderly with a low education level experienced cognitive impairment of $83.6 \% .^{10}$ Similar results was also found in a study at Bali, from a total of 84 elderly respondents, it were found $73.8 \%$ of respondents experienced cognitive impairment. ${ }^{11}$ However, this was not in line with a research conducted by Setiawan (2014), it said that there was no relationship between the level of education with the incidence of cognitive impairment in elderly respondents. ${ }^{6}$

Given hypertension is also said to be a risk factor for the incidence of cognitive impairment, where hypertension can lead to cerebrovascular disease such as stroke, blood pressure needs to be kept controlled in order to avoid any disturbance in the future. According to data from two studies, the Systolic Hypertension in Europe Study (Syst-Eur) and the Perindopril Protection Against Recurrent Stroke Study (PROGRESS), showed that treatment of high blood pressure with antihypertensive drugs may decrease the incidence of cognitive function impairment in the study subjects. ${ }^{12}$

Mini-Mental State Examination (MMSE) is a widely used examination as a standard measure for checking cognitive status. MMSE has been widely used in many countries and has been translated into various languages including Indonesian. MMSE has a maximum score of 30 with a normal interpretation of the score range between 24-30. This MMSE can be used to screen and recognize early symptoms of mild cognitive impairment (scores 21-26) to dementia (score below 20) so that prevention can be done by promotive, preventive, curative and rehabiliatif. ${ }^{7}$ 
Based on the description above, the authors feel the need to do a study about the cognitive status of elderly and the relationship between educational level and hypertension with decreased cognitive status in the elderly in the working area of Mengwi I Public Health Center, Mengwitani Village, Mengwi Subdistrict, Badung Regency. It is expected that the results of this study can be beneficial to the Health Office and related agencies for the improvement, planning and implementation of elderly health programs.

\section{METHOD}

This research is an analytic study with cross-sectional approach. The study was conducted in the working area of Puskesmas Mengwi I, Badung, Bali in August 2016. The study sample was all elderly patients who come to elderly polyclinic Puskesmas Mengwi I with inclusion criteria were patients with Age 60 years or more, Living in the working area of UPT Puskesmas Mengwi I, able to communicate well, willing to participate as a research subject and sign informed consent. Exclusion criteria were prospective respondents under the circumstances of not possible to answer the questionnaire. Criteria drop out were respondents resigned as research subjects in the middle of time research without reason and gave unsuitable data. Based on the calculation result, it takes a minimum number of samples of 23 people, in which the number of samples obtained was 41 people. Sampling was done by accidental sampling technique.

This research used the questionnaire as a research instrument. The questionnaire used was the MMSE Mini Mental State Examination questionnaire (MMSE) in Indonesian language version transformed into a medium to detect and follow the development of cognitive disorders associated

Table 1 Distribution of Respondents by Age Category

\begin{tabular}{lcccc}
\hline Age & Quantity & Percentage (\%) & Average & Standard Deviation \\
\hline $60-64$ & 22 & 53.7 & & \\
$65-70$ & 15 & 36.6 & 65.22 & 4.053 \\
$>70$ & 4 & 9.8 & & \\
Total & 41 & 100.0 & & \\
\hline
\end{tabular}

Table 2 Distribution of Respondents by Level of Education

\begin{tabular}{lcc}
\hline Level of Education & Quantity & Percentage (\%) \\
\hline Elementary (SD) & 15 & 36.6 \\
Junior High (SMP) & 7 & 17.1 \\
Senior High/Vocational high (SMA/SMK) & 10 & 24.4 \\
Diploma/Bachelor degree (Akademi/Sarjana) & 9 & 21.9 \\
Total & 41 & 100 \\
\hline
\end{tabular}

with neurodegenerative disorders. This instrument is recommended as screening for global cognitive assessment by the American Academy of Neurology. MMSE is a structured scale consisting of 30 points grouped into 7 categories: orientation to place (country, province, city, building and floor), orientation to time (year, season, month, day and date), registration (repeating with fast 3 words), attention and concentration (sequentially reducing 7 , starting from number 100, or spelling WAHYU word in reverse), recalling (recalling 3 previously repeated words), language (naming 2 objects, repeating sentences, read aloud and understand a sentence, write a sentence and follow 3-step commands), and visual construction (copying the image). MMSE can be implemented for approximately 5-10 minutes. MMSE scores are awarded based on the number of perfectly correct items, where lower scores indicate poor performance and more severe cognitive impairment. Rating scores range from 0 to 30 (maximum value). Interpretation of MMSE is based on scores obtained at the time of examination, ie the score of 24-30 is interpreted as a normal cognitive function, score 17-23 means probable cognitive impairment, and score 0-16 means definite cognitive impairment.

Data collection was done by filling out questionnaires and interviews. Informed consent of the respondents was made to ensure willingness in filling out questionnaires and interviews; then the respondents were asked to complete the question based on the questionnaire available. The data have been analyzed using SPSS software descriptively and bivariate analysis (chi-square test) to know the relation between independent variable with the dependent variable. The Independent variables of this research were education level and history of hypertension while the dependent variable was cognitive function status.

\section{RESULT}

The respondents of this study were elderly patients who visited elderly polyclinics aged 60 years or older, had signed informed consent forms and were willing to be screened and met the predetermined inclusion criteria.

Tabel 1. memaparkan distribusi responden berdasarkan kategori usia. Responden dengan kategori usia 60-64 tahun menempati urutan teratas dengan jumlah sebanyak 22 orang (53.7\%), sedangkan usia $>70$ tahun hanya terdiri dari 4 orang $(9.8 \%)$.

Table 2 showed the distribution of respondents by education level. Most of the respondents were with the level of elementary education is 15 people (36.6\%). 
Table 3 Distribution of Respondents Based on Hypertension History

\begin{tabular}{lcc}
\hline Hypertension History & Quantity & Percentage (\%) \\
\hline Yes & 18 & 43.9 \\
No & 23 & 56.1 \\
Total & 41 & 100 \\
\hline
\end{tabular}

Table 4 Cognitive Status of Respondents Based on Education Level

\begin{tabular}{lccc}
\hline & \multicolumn{2}{c}{ Cognitive Status } & \\
\cline { 2 - 3 } Education Level & Normal & Decline & Total \\
\hline Elementary $(S D)$ & 3 & 12 & 15 \\
Junior High $(S M P)$ & 5 & 2 & 7 \\
Senior High/Vocational high (SMA/SMK) & 9 & 1 & 10 \\
Diploma/Bachelor degree (Akademi/Sarjana) & 8 & 1 & 9 \\
Total & 25 & 16 & 41 \\
\hline
\end{tabular}

Table 5 Cognitive Status of Respondents Based on Hypertension History

\begin{tabular}{lccc}
\hline & \multicolumn{2}{c}{ Cognitive Status } & \\
\cline { 2 - 3 } Hypertension History & Normal & Decline & Total \\
\hline Yes & 12 & 6 & 18 \\
No & 13 & 10 & 23 \\
Total & 25 & 16 & 41 \\
\hline
\end{tabular}

Table 6 Relationship Between Education Levels with Decreased Cognitive Functions

\begin{tabular}{|c|c|c|c|c|c|}
\hline \multirow[b]{3}{*}{ Education Level } & \multicolumn{4}{|c|}{ Status Kognitif } & \multirow[b]{3}{*}{ p-Value } \\
\hline & \multicolumn{2}{|c|}{ Normal } & \multicolumn{2}{|c|}{ Decline } & \\
\hline & $\mathbf{n}$ & $\%$ & $\mathbf{n}$ & $\%$ & \\
\hline Elementary (SD) & 3 & $20.0 \%$ & 12 & $80.0 \%$ & \\
\hline Junior High $(S M P)$ & 5 & $71.4 \%$ & 2 & $28.6 \%$ & \\
\hline $\begin{array}{l}\text { Senior High/Vocational high } \\
(S M A / S M K)\end{array}$ & 9 & $90.0 \%$ & 1 & $10.0 \%$ & 0.001 \\
\hline $\begin{array}{l}\text { Diploma/Bachelor degree } \\
\text { (Akademi/Sarjana) }\end{array}$ & 8 & $88.9 \%$ & 1 & $11.1 \%$ & \\
\hline Total & 25 & $61.0 \%$ & 16 & $39.0 \%$ & \\
\hline
\end{tabular}

${ }^{*}$ chi-square

Table 7 Relationship Between Hypertension History with Decreased Cognitive Function

\begin{tabular}{lccccc}
\hline & \multicolumn{5}{c}{ Status Kognitif } \\
\cline { 2 - 5 } $\begin{array}{l}\text { Hypertension } \\
\text { History }\end{array}$ & \multicolumn{2}{c}{ Normal } & \multicolumn{2}{c}{ Normal } & \\
\cline { 2 - 5 } p-Value \\
\hline Yes & $\mathbf{n}$ & $\%$ & $\mathbf{n}$ & $\%$ & \multirow{2}{*}{0.509} \\
No & 12 & $66.7 \%$ & 6 & $33.3 \%$ & \\
Total & 13 & $56.5 \%$ & 10 & $43.5 \%$ & \\
\hline
\end{tabular}

${ }^{*}$ chi-square
Table 3 showed the distribution of respondents based on the presence or absence of hypertensive history according to data on medical records. Based on the data obtained there were 18 people (43.9\%) of respondents had a history of hypertension, and as many as 23 people (56.1\%) had no history of hypertension.

In this study, obtained 25 (61\%) respondents with normal cognitive function and 16 (39\%) respondents with decreased cognitive function. Table 4 showed the distribution of cognitive status of respondents based on the last level of education of respondents. Table 5 showed the distribution of cognitive status of respondents based on the presence or absence of a history of hypertension.

Based on Table 6, it can be seen that there was a significant correlation between educational level and decreased cognitive function with $\mathrm{p}$-value $<0.05(p=0.001)$. Table 7 showed that there was no significant correlation between a history of hypertension and decreased cognitive function in this study with $\mathrm{p}$-value $>0.05(\mathrm{p}=0.509)$.

\section{DISCUSSION}

Based on the results of this study, showed that most of the respondents were with female sex (61\%). This result is similar to the research conducted by Setiawan et al. (2014) which showed that elderly women were female (66.7\%) more than male (33.3\%). Lachman et al. (2010) also showed more elderly women (55.4\%) than men (44.6\%). ${ }^{13}$

According to the results of this study, using MMSE questionnaires, from 41 samples, it was found $61 \%$ of samples with normal cognitive function and $39 \%$ of samples with decreased cognitive function. In a study conducted by Wu et al. (2011) obtained a sample with normal cognitive function as much as $26.9 \%$ and cognitive function decreased by $18.0 \% \cdot{ }^{14}$ In the study it was found that there was a significant correlation between educational level and decreased cognitive function. It may indicate that samples with low educational levels may experience cognitive decline later in life. Samples with a high level of education can make a healthy lifestyle associated with a cognitive function that because the brain will continue to be stimulated during everyday activities. The same result was also found by Lachman et al. (2010) that elderly with low educational level has shown worse cognitive function.

A low level of education is said to be associated with a decrease in cognitive function that can occur more quickly than high levels of education. Presumably, several mechanisms are underlying this process. "The brain reverse hypothesis" theory 
said that education levels and cognitive function decline due to age are interconnected as both are based on cognitive potential gained from birth. The theory of "use it or lose it," said the stimulus mental during adulthood was a protection against the decline in early cognitive function. Early life education influences the next life; if a person continues his education to stimulate mental, it is thought to be beneficial to neurochemistry and affect the brain structure. $^{15,16}$

This study obtained the elementary school $(36.6 \%)$ was the most proportion education level of the respondents. According to research conducted by Wu et al. (2010), which showed a correlation between the low level of education with decreased cognitive function, also showed the lowest level of education occupied the highest proportion of $29.6 \% .^{14}$

Related to the theory of "cognitive reserve hypothesis," the educated person has more synapses in the brain and can compensate well for the loss of skill by using alternative strategies, whereby the ability develops from the exam or test obtained from training during the education process. It is assumed that a highly educated person has the flexibility in compensating for cognitive impairment through a test-taking strategy. ${ }^{17}$

This study showed a significant correlation between the level of education with a decrease in cognitive function with a value of $\mathrm{p}=0.001$. Research conducted by Wu et al. (2011) also stated that cognitive function impairment is a matter that is related to age condition and also one of them is low education level. ${ }^{14}$

This study showed there was no significant correlation between a history of hypertension with decreased cognitive function with p-value $=0.509$. The different result showed in the research conducted by Reitz et al. (2007), it was indicating that hypertension is associated with a decreased cognitive function $(p=0.02)$. It was due to the underlying mechanism that increased blood pressure can produce hypergensity in the white matter of the brain or may also induce a lacunar brain infarction that may eventually lead to a decrease in cognitive function. There were different types of research design, and the number of samples was quite a lot. The Research conducted by Reitz et al. (2007) used a longitudinal cohort study design type that allowed further evaluation of the association between hypertension and cognitive function decline with 918 samples, which can obtain a wider variety of samples. ${ }^{18}$

The absence of a significant correlation between a history of hypertension and cognitive impairment may be due to several factors. The number of samples was relatively small compared with the same previous study. It makes the uneven distribution of age, sex, and history of hypertension thus making the data to be non-varied and did not reflect the actual community conditions.

\section{SIMPULAN}

A study conducted on elderly patients who visited the elderly polyclinic of Mengwi I Public Health Center at the age of 60 years or older, found a significant correlation between educational level and decreased cognitive function in elderly. However, there was no significant correlation between a history of hypertension and decreased cognitive function in elderly.

For further research, it was recommended to analyze other variable relating to the cognitive functions or carry out similar research with a wider scope of territory.

\section{DAFTAR PUSTAKA}

1. Noveria M. Challenges of Population Ageing in Indonesia. Conference on Impact of Ageing: A Common Challenge for Europe and Asia. Research Center for PopulationIndonesian Institute of Science. 2006; p7-9.

2. Lestari W., Ngestiningsih D. Hubungan Antara Status Kognitif dengan Status Fungsional Lanjut Usia Panti Wredha di Semarang. Semarang; Universitas Diponegoro. 2013.

3. Nugroho W. Keperawatan Gerontik dan Geriatrik. Jakarta; EGC. 2006.

4. Nevriana A., Riono P., Rihardjo T., Kusumadjati A. Lifetime Musical Activities and Cognitive Function of the Elderly. Jakarta; Universitas Indonesia. 2012.

5. Ramadian D., Maja J., Runtuwene T. Gambaran Fungsi Kognitif Pada Lansia Di Tiga Yayasan Manula di Kecamatan Kawangkoan. Manado; Universitas Sam Ratulangi. 2012.

6. Setiawan D., Bidjuni H., Karundeng M. Hubungan Tingkat Pendidikan Dengan Kejadian Demensia Pada Lansia Di Balai Penyantunan Lanjut Usia Senja Cerah Paniki Kecamatan Mapanget Manado. Manado; Universitas Sam Ratulangi. 2014.

7. Chertkow H., Feldman H., Jacova C., Massoud F. Definition of Dementia and Predementia States in Alzheimer's Disease and Vascular Cognitive Impairment: Consensus from The Canadian Conference on Diagnosis of Dementia. BioMed Central. 2013; 5(1): S2.

8. Stanley M., Beare P. Buku Ajar Keperawatan Gerontik. Edisi ke-2. Diterjemahkan oleh: Nety Juniarti \& Sari Kurnianingsih. Jakarta: EGC. 2007.

9. Larasati T. Prevalensi Demensia di RSUD Raden Mattaher Jambi. Jambi; Fakultas Kedokteran dan Ilmu Kesehatan Universitas Jambi. 2013.

10. Ramadian D., Maja J., Runtuwene T. Gambaran Fungsi Kognitif Pada Lansia Di Tiga Yayasan Manula di Kecamatan Kawangkoan. Manado; Universitas Sam Ratulangi. 2012.

11. Sundariyati H., Ratep N., Westa W. Gambaran FaktorFaktor yang Mempengaruhi Status Kognitif Pada Lansia di Wilayah Kerja Puskesmas Kubu II, Januari-Februari 2014. Denpasar; Universitas Udayana. 2014.

12. Igase M., Kohara K., Miki T. The Association Between Hypertension and Dementia in The Elderly. Int J Hypertens. 2012; p1-6.

13. Lachman M., Agrigoroaei S., Murphy C., Tun P. Frequent Cognitive Activity Compensates for Education Differences in Episodic Memory. Am J Geriatr Psychiatry. 2010. 18(1): 4-10. 
14. Wu M., Lan T., Chen C., Chiu H., Lan T. Socip-demographic and health-related factors associated with cognitive impairment in the elderly in Taiwan. BMC Public Health. 2011. 11(22): 1-8.

15. Bosma H., van Boxtel M. P. J, Pomds R.W. H, Houx P. J. H, Jolles J. Education and Age- Related Cognitive Decline the Contribution of Mental Workload. Educational Gerontology. 2003. 29: p165-173.

16. Lee S., Kawachi I., Berkman L. F., Grodstein F. Education, Other Socioeconomic Indicators, and Cognitive Function. American Journal of Epidemiology. 2003. 157:712-720.
17. Dash P., Villemarette-Pittman N. Alzheimer's Disease. New York: American Academy of Neurology. (2005).

18. Reitz C., Tang M., Manly J., Mayeux R., Luschinger J. Hypertension and the Risk of Mild Cognitive Impairment. Arch Neurol. 2007. 64(12): 1734-1740.

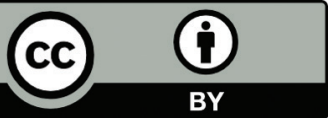

This work is licensed under a Creative Commons Attribution 